

\section{The birth of modern London}

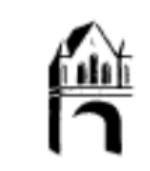

MANCHESTER

UNIVERSITY PRESS 


\section{Henry Ford}

Mass production, modernism and design

RAY BATCHELOR

The culture of fashion

A new history of fashionable dress

CHRISTOPHER BREWARD

\section{Pioneers of modern craft}

Twelve essays profiling key figures in the history of contemporary crafts EDITED BY MARGOT COATTS

\section{Manufactured pleasures}

Psychological responses to design

RAY CROZIER

The culture of craft

Status and future

EDITED BY PETER DORMER

\section{Eighteenth-century furniture}

CLIVE D. EDWARDS

\section{Twentieth-century furniture}

Materials, manufacture and markets

CLIVE D. EDWARDS

\section{Victorian furniture}

Technology and design

CLIVE D. EDWARDS

\section{Graphic design}

Reproduction and representation since 1800

PAUL JOBLING AND DAVID CROWLEY

\section{The Edwardian house}

The middle-class home in Britain 1880-1914

HELEN C. LONG

\section{Eighteenth-century ceramics}

SARAH RICHARDS

American design in the twentieth century

Personality and performance

GREGORY VOTOLATO 


\section{The birth of modern London}

The development and design of the city 1660-1720

Elizabeth McKellar

Manchester 
Copyright (c) Elizabeth McKellar, 1999

The right of Elizabeth McKellar to be identified as the author of this work has been asserted by her in accordance with the Copyright, Designs and Patents Act 1988

Published by Manchester University Press

Altrincham Street, Manchester M1 7JA

http://www.man.ac.uk/mup

British Library Cataloguing-in-Publication Data

$A$ catalogue record for this book is available from the British Library

Library of Congress Cataloging-in-Publication Data applied for

$\begin{array}{lll}\text { ISBN } & 0719040752 & \text { hardback } \\ & 0719040760 & \text { paperback }\end{array}$

First published 1999

05040302010099

10987654321 